\title{
Famous Governors of Multan Under the Sikh Regime in Punjab
}

\author{
Ahmad Ali ${ }^{1}$, Shahid Hasan Rizvi², Khizar Hayat ${ }^{3}$ and Muhammad Akbar \\ ${ }^{1}$ Lecturer at Govt. Degree College Mailsi, The Islamia University of Bahawalpur, Pakistan \\ ${ }^{2}$ Chairman Department of History, The Islamia University of Bahawalpur, Pakistan \\ ${ }^{3}$ P.S.T. at G.P.S. Kotla Dilbar, The Islamia University of Bahawalpur, Pakistan \\ ${ }^{4}$ S.S.S. at G.H.S.S 53 M, The Islamia University of Bahawalpur, Pakistan
}

Submission: July 21, 2018; Published: November 05, 2018

"Corresponding author: Ahmad Ali, Lecturer at Govt. Degree College Mailsi and PhD Scholar, The Islamia University of Bahawalpur, Pakistan

\begin{abstract}
Maharaja Ranjit Singh had numerous Hindu Officials and Courtiers at Lahore Durbar because he needed to utilize their services in civilian setup to grow and build his Kingdom. Undoubtedly, he required to inject the soul of rivalry, chastisement and proficiency in his various officials and courtiers so that he could merge his place and would have the capacity to enlarge his Realm without much trouble. By utilizing them, he also proved the secular scenario of his Empire. He, according to his necessities, fully utilized the competence of these Hindu Courtiers. It will be worth specifying that some of these were unfortunate and disappointed with their past services, so they could get any status, either a General or a clerk, on the ground of legitimacy. Among them, following pioneers were appointed the Governors in Multan whom played a vital role in politics, civil as well as military administration, economics, agriculture, irrigation and land revenue etc.
\end{abstract}

Keywords: Ranjit Singh; Sawan Mal; Mulraj; Anglo-Sikh Wars; The British; Dogra Brothers

\section{Introduction}

The land of Multan has been remained the target of insurgent activities of the foreign invaders and dictators. These foreign forces not only exploited its brave, hardworking, fearless and dauntless people but also divided it into pieces. They attracted the local people with the lust for earning and enrolled them in the army because their sole aim was to prepare them for fight against their accused enemies. These foreigners belonged to different religions, civilizations and geographical tracts. Multan has also enjoyed the Muslims rule for three centuries. During this period, it maintained its social, political and religious position till 1707. Multan was a vital province which was vanquished by Ranjit Singh in 1818. He, till the permanent governor of Multan, ordered to Misr Diwan Chand to stay here for proper arrangements. At that time, its condition was far behind from attractive [1]. Individuals of the city had been lustfully plundered by the Sikh soldiery. The agriculturists had surrendered the fields and the populace had betrayed the town. The silk makers and weavers had stopped their activities and the trade was at a halt [2]. During the Sikh period, the Muslims had to face tyranny and injustice. From 1818 to 1821, many changes occurred in the history of Multan and six Nazim (governors) were appointed in which Sukhdayal was the first [3].

\section{Statement of the Problem}

After the death of Aurangzeb Alamgir, the Mughal Empire began to scatter. At last Ahmad Shah Abdali conquered Multan in 1752. In 1766, the Sikhs and the Afghans fought many battles but the most important and decisive adventure occurred in 1818. During this battle, Ranjit Singh conquered Multan and killed Muzaffar Khan, the governor of Multan, and succeeded in establishing the Sikh Raj here. The Sikhs, in such a way, looted, killed the masses and destroyed Multan that history will not face such kind of destruction and catastrophe. The political circumstance also stayed extremely melted and geo-political changes frequently occurred so that no unfaltering predominant proprietorship was made. Different Muslim feudal chiefs were staunch supporters of the Sikhs, yet this was not satisfactory to protect their control in the Punjab. During his regime in Multan, he appointed many Governors (Nazims) one after the other but no one, in prestige and reputation, could reach to Sawan Mal. After having been appointed the Governor of Multan, he reconstructed Multan and attended towards his subjects. So, keeping all these occasions, conditions and essentialness of this period as a primary concern, I decided to conduct a research entitled with "Famous Governors of Multan under the Sikh Regime in Punjab"

\section{Hypothesis/Research Questions}

a) Personalities exist but it is conceptualized in collective terms. Is it true?

b) Can a system of check and balance serve as a check on popular political passions? 


\section{Significance of The Study}

The first half of the nineteenth century was a time of radical changes in the Punjab, especially in Multan, which was dominated by the Sikhs. During proposed period, the Muslim rule was on the verge of closure and the new Sikh rulers were attempting to obtain the entire Subcontinent. The present work related to the politico-economic lifestyle of the general population of Multan and the governmental system from 1821 to 1843 . Its main aim is to examine the role of invaders of Multan in promoting or demoting Sikh rule and development and is to highlight the origin and role of Ranjit Singh in history of Multan. This period is momentous in the historical backdrop of Multan because it was the time of decay of the Mughal-Afghan reign and the rise of the Sikhs. They rose as autonomous rulers of the Punjab, including Lahore, Multan, Peshawar and Kashmir, by dint of their own arms and forecasted to build up a jurisdiction under Ranjit Singh. Multan stayed under Muslim power for about eight centuries, however, disappointingly, no steady and secured control could build up here and the populace, remained destitute, offensive and backward in perspective of socio-political and financial conditions.

\section{Literature Review}

After the fold of the Mughal Empire, the bigger part of the Punjab was again attached to the Sikh kingdom. This work has a multidimensional structure in which local history, the attitude of trespassers towards people of Multan, traditions and its reaction has been covered. History of the Sikh rule in Multan indicates its hostility and, a long time ago, settled custom of communal bitterness. Local historians have also observed all the disparities and profound religious resentment in pre-colonial Punjab. For instance, the general population of Multan can be seen in the shape of three groups: the Muslims, the Hindus and the Sikhs, yet there was not a single parameter in native historian's works by which we could separate the general population of Multan into social gatherings. The criteria, they utilized, ranged from sectarian belief, religion, occupation and tribe.

Other than this, the formation of local identity draws out the design of regional contrasts. Local history is productive for local studies. It, more extensively, highlights the regional conditions as well as present angle of dream to look at challenging situations. Furthermore, the regional history, when a locality has more extensive part to play in its geographic situation, becomes significant to understand general histories. Sukhdayal was the first governor of Multan. According to Kohli (1971), he was a vital Hindu of Ranjit Singh's court and he, as a Nazim of Multan, got salary of 36000 rupees per annum [4-7]. He participated in the initial campaign of Attock in 1812 and captured it in 1813 which proved a gateway towards the territories of the North-West [8]. At that time, it was under the control of Jahandad Khan who was the brother of Ata Muhammad Khan and the Governor of Kashmir $[9,10]$. Ranjit Singh concentrated on its key preference and persuaded that he did not check and tide the trespassers unless he would conquer it.
After the victory of Kashmir, Jahandad Khan felt that the ball is in his court, so he met Ranjit Singh and consented to surrender the citadel on the condition that he would be given legitimate help to expel Wazir Fateh Khan from the fort. (Murray, 1846) Ranjit Singh quickly offered him the Pargna of Wazirabad as a Jagir and dispatched his armed forces under the headship of Fakir Aziz-udDin, Bhawani Das, Mit Singh and Sukhdayal to assume charge of the Attock Fort [11,12].

In 1817, Jhang had also granted him at the cost of 400000 rupees and then it was raised to 410000 in 1821 [13]. On June 02, 1818, Multan was apprehended, and a huge plunder fell to the Sikh troops. Sukhdayal repaired fortress by financing of 3000 rupees daily [7]. He attained the Ijara of the Sairat for thirteen lac rupees. Under the Sikhs, the Ijardari framework was not limited to the lands. Truly, taxes or Sairat other than the land revenue were also given in Ijara to imperative and liable authorities of the State [7]. However, in Kashmir and Multan, Ijara could be substitute with direct accumulation. The magnitude of revenue, gathered through Ijara, seemed to have been significant. In many areas, the quantity of the Ijara was close to the quantity of the revenue on behalf of the Government. The Ijaradar was given a little edge to meet the costs, regarding the collection, to get his share of benefit. Yet, the Mushakhasa was also enforced in the light of records of collections. If the income of a specific region expanded, the revenue of Ijara was raised too. Before giving a region in Ijara, the Maharaja got the right data with respect to the wage from the revenue of that region. By commenting on Sukhdayal, the Maharaja mentioned that he was an extremely valour and brave man, so he, for his preservation, granted him a home of 10000 rupees [11,12]. As I described that he received 36000 rupees per annum, yet he could not gather revenue competently and the Maharaja detached him on the charges of misuse of State duties in September 1819 [14]. The Suba was then handed over to Sham Singh for a yearly sum of 650000 rupees.

The second governor of Multan was Sham Singh. During the Sikh Kingdom, mostly Ijaradars related to the Government and Sham Singh Peshawaria as well as Diwan Sawan Mal were also regarded as colossal Ijaradars. The Zamindars could submit grievances against the Ijaradars before the Maharaja. Furthermore, the Ijaradars could protest the imperiousness of the high-ups of the Government officials and their cultivators [12]. Similarly, when Diwan Kirpa Ram, Nazim of Kashmir, could not pay revenue to the Maharaja, Sham Singh, the Jamadar of Dewhri, was sent to confiscate his property at Kunjah. Sham Singh, with the help Nazar Ali, governed at Multan harshly. Sham Sigh also could not deal with Multan properly and failed to submit fixed revenue. Other than this, the officials poisoned the Maharaja's mind by telling him that he would make upheaval and never come to meet the Maharaja [10].

Therefore, the Maharaja sent instructions recurrently to visit him. At last, the Maharaja reached Multan through Chaniot and stayed here for three months [14]. But, when he reached Lahore, the Diwan was instructed to pay the pending revenues along with 
the fine. He was not able to pay this and thus he was removed from the governorship and then detained him. The Toshahkhana of the Diwan was apprehended too. However, on hearing the news of his disrepute, the people of Multan enjoyed the celebrations. Owing to his pitiless despot, it was justified to punish him even for the minimum offensive [15].

The third personality, who governed in Multan as a governor, was Bhai Badan Hazari. After Sham Singh's removal, the Maharaja appointed Badan Hazari as the next governor of Multan. In 1820, Sawan Mal joined him as the head of the record office at a wage of 250 rupees per month. Badan Hazari attempted his best to set right the finance of Multan which was in perplexity. Due to some reasons, Badan Hazari and Sawan Mal quarreled with one another. As a result, Sawan Mal was made the chief of Shujabad in 1820.

Badan Hazari also could not handle Multan and failed to submit settled revenue. After a brief time, he was also dismissed and imprisoned [14]. Gilani cites Major Edward's book in these words: He is alive and healthy and working as Darogha of Magazine in Lucky Marwat at salary of one rupee per day. He never saw such kind of unreal and rascal person in his life. It is believed that he has been granted the governorship of Multan merely as a joke because he had not a little sense of politics and clout. He is neither educated nor valour. After him, Mehta Mal Shikarporia, Jamadar Baj Singh and Siva Mal were appointed as governors of Multan for a brief period. Yet, their enough record in history of Multan was not found because they had been appointed for a very short period.

They also could not run the Suba in proper manner and were removed from the governorship [3]. Sawan Mal stands sixth in number as governor of Multan. From 1818 to 1821, above six governors could neither maintain law and order situation nor as good management in Multan. Besides this, they could not gather revenue proficiently, so the Maharaja evacuated and detained them. At last in 1821, he appointed Sawan Mal as the governor of Multan who had already pulled in the consideration of the Maharaja [7]. Great may thy name be, Lala Sawan Mal Thou last repopulated a ruined country [4]. Sawan Mal was a Khatri of Chopra sub-caste from Akalgarh in Gujranwala region [16,17]. He was born in 1788 [18-22]. His father, Hoshnak Rai, was an employee of Sardar Dal Singh of Akalgarh [23]. Hoshnak Rai had three sons and Sawan Mal was the youngest one. Sawan Mal started his profession in the office of his elder brother Nanak Chand who worked with Diwan Mohkam Chand. In 1820, he participated as the head of the record office under Governor Bhai Badan Hazari at a monthly payment of 250 rupees [21].

In a brief time, he set right the record of Multan which was in a practically inseparable misperception. As a decent scholar of Persian and Arabic, he won the gratitude of the Maharaja for his Insight and secretarial aptitudes and rapidly rose to sophisticated positions. Truly in 1821, another period unfolded when Sawan Mal was designated as Kardar of the half area of Multan. Besides this, Shujabad was also handed over to him. Within two years, the income of this Ilaqa expanded by $50 \%$ and the Maharaja gave him Multan in Ijara too [24]. In 1829, he was made the Nazim of the entire province and held this office till 1844 [25-28]. Besides this, different Ilaqas were added to the Diwan's agreement until he held most of the regions which fell under the Governorship of Multan. These were Montgomery, Jhang, Dera Ismail Khan as well as and Dera Ghazi Khan and Muzaffargarh. In December 1832, he was awarded the title of Diwan by the Maharaja. He worked as a Kardar in the Pargna Ram Nagar and Hafiz Abad too [29]. During a brief period, he changed the entire appearance of the province by introducing unique and innovative reforms.

$\mathrm{He}$ regulated equity with solid and unbiased efforts. He dedicated his entire energies to the betterment of his charge and its restoration from the rot into which it had collapsed owing to the battles and uproars of the late years. His impartiality was eminent for his justice. He was an extremely thoughtful and generous administrator. Ranjit Singh was constantly satisfied with his services to the general population [23]. Amid his life time, Sawan Mal had allotted the supervision of some of the domains of Multan to his two sons. Mulraj, the eldest son, ruled Shujabad and Jhang while Karam Narain was made the chief of Leiah. During the sovereignty of Maharaja Ranjit Singh, he expanded his force step by step, yet he never got to be revolted. He was minimal irritated; however, he paid his compliment with such consistency that there was no reason for protest [30]. Diwan Sawan Mal was the arc adversary of the Dogra brothers who had deep impact on Ranjit Singh.

After Ranjit Singh's demise, the Dogra brothers endeavored to devastate him, yet they could not be fruitful in their goal. Amid the reign of Kharak Singh, Sawan Mal was instructed to build a fortress at Mithan-Kot [20]. In Multan, he, with a sight to inspire trade by the way of river, instructed to construct a Gunj at Adam Wahin. $\mathrm{He}$, for incitement of the traders, reduced the domestic duty of Merchandize one half. As a result, a few of the most dominant traders of Multan had set up a branch of their business. During his regime, a solitary intruder did not occur in Multan. It was a great achievement of his regime [31-36]. During Nau Nihal Singh's era, the Dogras became so influential that they suggested the Maharaja to call Sawan Mal at Lahore Durbar to submit the records of fifty lakhs rupees. In September 1840, he was called, yet he failed to comply. (Foreign Department, Secrte Consultation, October 20, 1840) It was decided to send the troops against him, yet, due to his shrewdness, he succeeded in scrutiny of his records. For this purpose, he paid 100000 rupees to Ram Singh and Gobind Ram, 50000 rupees to Raja Dhian Singh and Hira Singh, 25000 rupees to Diwan Dina Nath, 25000 rupees to Sardar Fateh Singh Mann and 100000 rupees to Rani Chand Kaur. After this friendly agreement, he came back to Multan. In March 1841, when Maharaja Sher Singh had recently got the incomparable power, Dhian Singh attempted to poison the Maharaja's brain against him. The Maharaja engaged both Sawan Mal and Dhian Singh to increase new entities with which to substitute a portion of the stormy Khalsa soldiery [37]. Diwan Sawan Mal, with the genuine object of shielding himself 
against Dhian Singh, started to increase the Muhammadan troops. On the other hand, Raja Dhian Singh was not less dynamic. He, to overpower Sawan Mal and to defend Jammu, was preparing his new troops against the British and the Sikhs.

On December 16, 1841, the Raja insisted the Maharaja to expel Sawan Mal from Multan, yet the Maharaja replied him to keep quiet until the landing of Raja Gulab Singh and Kanwar Partap Singh at Lahore [37]. On April 23, 1842, Diwan revealed that he had represented the whole province of Multan for a long time and now he was demanded an explanation due to the deceptions of some intrigued individuals. He expressed his availability and pleaded the Maharaja not to listen his adversaries. Devi Ditta, Sawan Mal's nephew, was instructed to ask his uncle to submit the accounts and not to suspend it. The Mazari tribe, due to the inconvenience of the Sikh governors, began to loot Rojhan in January 1842. However, Sawan Mal marched against them and constrained to retreat.

Like the Dogras, Gurmukh Singh was not harmonious to Sawan Mal because he had affectionate terms with Bhai Gobind Ram and Bhai Ram Singh. Gurmukh Singh was not happy with them since Ranjit's era. This situation perplexed Sawan Mal and thus he, from dawn to dusk, engaged in assembling his own actions with both Bhais and the Sandhawalias. On April 26,1842, reports at Ludhiana expounded the correspondence between Bhais and Sawan Mal. On this Raja Dhian Singh watched that the Maharaja's employees were exceptionally treacherous. But, after the assassination of Dhian Singh, the Diwan freed from his cleverest foes because Gulab Singh was also feeling threat to the Diwan [32]. Pundit Jalla decimated Raja Gulab Singh with the help of the Sikh armed forces and then planned to annihilate Diwan Sawan Mal but he was killed by the troops in December 1844 [38].

After that, Sawan Mal began to interact with the British. It is noteworthy that he achieved some auspicious chances to divert his faithfulness to Lahore Durbar and announce his freedom, yet he did not do so because he had consumed so much cash and worked at Multan. In 1844, three regiments of mounted troops and forty-six little and enormous guns under his charge [39]. Sawan Mal had an appalling end. On September 16, 1844, when he was riding near the historical prison in the city, an Afghan grabbed a gun from one of his Guards and fired at him [14]. He tumbled from his horse and had quickly dispatched him to his dwelling in a state of obliviousness. In the morning, he slightly recouped and gave expansive sums in philanthropy and instructed that the man who sacked at him ought to be killed. Yet, because of that injury, he expired on September 29, 1844 [40]. In this way, deceased the shrewdest and best of every Sikh governor.

Edwards has narrated an alternate event of his demise in these words: Murderer was a soldier who had worked devotedly for a long time. He came to Durbar to request against his wage and expulsion. Sawan Mal not only negated his demands but also affected him with his uncovered sword. He instructed him to go out from Durbar. So, the warrior, in retaliation for the critical abuse, shot him [41]. He was a shrewdness, sincere and a tolerant man [42]. He left a huge entirety of seventy lakhs rupees which had been accumulated during twenty-three years of blameless governorship. His inheritance was partitioned among his six sons. At the stage of his demise, he was almost fifty-six years old.

He sustained his work in the office till his final gasp. He was a man of incredible vigor and capacity and the richness of the region is mainly inferable from his management [43]. He was the most imperative administrator who presented imaginative modifications in Multan and granted an incredible distinction to the Sikh Kingdom. In the provincial management, his commitment was exceptional. He, with respect to diligent work, showed a gigantic capability and introduced incredible changes [14]. Roseberry quotes Edwards, statement in these words: He served Sawan Mal for three years and sat before him at Durbar where he transacted business every day.

During that period, he never heard one foolish word come out of his mouth [44]. Sawan Mal displayed himself effective and dynamic in each ground and performed awesome duties in the arena of judiciary. Throughout his governorship, various masonry wells were dug up. He made canals in the surroundings of Multan and gave an incentive force to commerce, business and industry. He encouraged colonization by giving land and insurance to the individuals. In this way, he transformed the barren areas into a developed one. His revenue improvements depended upon the standards of low excise duties and taxes. Adequate evaluation and diminishment in additional charges enforced on the cultivations. These flourishing activities pulled in the consideration of some renowned Britishers and travellers who came here to pass various circumstances. In the fight between Sawan Mal and the Dogras, Ranjit Singh supported the Dogras, yet he neither committed a revolt nor distorted his influence and vitality [40]. His regime is still respected by the general population.

They, irrespective with the Muslim, the Sikhs, the Hindus, the Pathan, the peasant and the labourer, gained something from his government. A few people say that he had partialities against the Mohammedans. It is most apparently fallacious. He was fair and tried his best to provide decent rule to the community [36]. He should be called one of the best Governors. He could use pen and sword equally well and it involved extraordinary credit to him [23]. The last governor of Multan, who governed the province of Multan, was Diwan Mulraj. Sawan Mal had six sons, one of them was Mulraj who became his successor. No record was found about his actual date of birth, yet, evidences proves that he was born in 1814. Sawan Mal had allotted the supervision of some of the domains of Multan to his two sons. Mulraj, the eldest son, ruled Shujabad and Jhang while Karam Narain was made the chief of Leiah [14]. But after his death, Mulraj was appointed as the Nazim of Multan.

The conditions for the governorship were that he would pay definite quantity to the Lahore Durbar annually. These terms and conditions had been liked by his father who had saved 900000 rupees too [28]. When Mulraj was affirmed as governor, the 
British raised its yearly tribute from 25000 to 30000 rupees. (Gilani, 1938) In 1846, he, knowing that Prime Minister Lal Singh was intense to displace him, admitted all the settings enforced on him [16]. Afterwards, the British eradicated definite duties in the province without decreasing that amount of Ijara which was remunerated by the governor. The purpose of this action was to destabilize his legal powers so that he could not create typical collection. These activities of the British Government caused of his insurgency. Similarly, after the end of first Anglo-Sikh War, Lahore Durbar claimed him to pay revenue. He refused the compliance, so the British referred the troops against him. Both met force by force and he defeated the Lahore troops near Jhang [45]. The British then interfered and the following treaty was signed [28].

The request of his resignation should be admitted but this resignation should be retained underground from Lahore Government. It should take effect from the end of the following April till the submission of revenue by Mulraj. Two or three months before his resignation, two British officials should proceed to Multan and he should pledge the State and ultimately install its charge. This pact did not gratify him because it restricted him just for his father's district. Furthermore, the people, knowing his irritating transfer and enforcing the eliminated taxes, discontented with the monetary system on which Sawan Mal had grown prosperous [46]. In all these circumstances, Mulraj displayed his failure to pay this tribute and sent his resignation in December 1847.

This resignation was accepted by the British and Lahore Durbar on March 24, 1848. This resignation produced a power space in South-Western Punjab and caused violent penalties for the complete Land of Five Rivers [44]. After this resignation, Sardar Kahn Singh was nominated the governor and he, along with Agnew and Anderson, was sent to Multan to assume the charge [3]. On April 16, 1848, they reached here with 500 horses and cavalry [14]. On April 19, 1848, when they came to Multan, Agnew and Anderson were slaughtered and Kahn Singh was detained by the Sikh fighters [5]. This incident occurred due to the conspiracy of Mulraj's brothers because they were desirous of to see him at the governorship. Mulraj had no idea to rebel, yet this incident compelled him to do so against the British.

On getting the initial report from Agnew, on April 21, 1848, Sir Frederick Currie decided to send the troops under the headships of Dina Nath, Sher Singh Attariwala and Shamsher Singh Sandhawalia on April 21, 1848. Yet, it was delayed on April 24, 1848. During this break, Jhanda Singh Butalia was sent to destroy Chattar Singh Attariwala's revolt [22]. This mission flopped as previous one too because Chattar Singh was a strong-minded and upheld by the Sikhs. It is said that Dina Nath was a double crosser [38]. He did not care of the measures adopted by the British Government for rebuffing the traitors. He also did not dread by the seizure of his Jagirs and balancing the plots of the revolutionary. Yet, amid the second Anglo-Sikh War, Sahib Dayal stayed loyal to the British [32,33].
Bhai Maharaj Singh, having an expansive number of warriors, marched from Majha to Multan to join the rebellious Mulraj in June 1848. Yet, Sahib Dayal assaulted and scattered his armed forces [22]. In November 1848, he was chosen Commander-inChief by Lahore Durbar [47]. In 1849, Devi Sahai joined Mulraj and exhibited his ability during the siege of Multan. He battled the war of Chillianwala but, after its occupation, all his Jagirs were seized [48]. Mulraj died near Buxur on August 11, 1851, at the age of only 36 years [9]. This brought awful devastation to his family and inhabitants of Multan. His family, containing of his wife, son and daughter along with Sawan Mal's three widows, three sons, a sister and a daughter-in-law, affected the most [9]. In October 1850 , these unfortunate people were brought by William Ford and kept them in very penniless environments in a single room [4952].

\section{References}

1. Yousef, RS (2004) Tazkirat-ul-Multan. (M. B. Abuhari, Trans). Saraiki Research Center, Multan, Pakistan.

2. Hasrat, B (1977) Life and Times of Ranjit: A Saga of Benevolent Despotism. V.V. Research Institute, Hoshiarpur, India.

3. Abd-ul-Haq, DM (1994) Multan Kay Badshah, Namwar Governor Aur Hamlah Aawar. Beacon Books, Multan, Pakistan.

4. Kohli, SR (1932) The Multan Outbreak and the Trial of Diwan Mulraj. Journal of Punjab Historical Society. P. 29-33.

5. Kohli, SR (1967) Sunset of the Sikh Empire. Orient Longmans, New Delhi, India.

6. Kohli, SR (1971) Land Revenue Administration of Maharaja Ranjit Singh. Govt. of the Punjab, Lahore, Pakistan.

7. Amarnath, D (1928) Zafarnama-i-Ranjit Singh (S. R. Kohli, Ed.). Punjab University, Lahore, Pakistan.

8. Shah, B (1848) Tareekh-i-Punjab (Vol. 4). Punjabi University, Patiala, India.

9. Ahluwalia, M (1963) The Punjab Pioneer Freedom Fighters. Orient Longmans Ltd, Bombay, India.

10. Ali-ud-Din, M (1963) Ibratnama (Vol. 2). Raj Publishers, Jullundur, India.

11. Suri, SL (1887) Umdat-ut-Tawarikh (Vol. 2). S. Chand, Delhi, India.

12. Suri, SL (1974) Umdat-ut-Tawarikh (Vol. 3) (V. Suri, Trans.). Guru Nanak Dev University, Chandigarh, India.

13. Steedman, E (1882) Report on the Revised Settlement of the Jhang District of the Punjab 1874-1880. Govt. of the Punjab, Lahore, Pakistan.

14. Gilani, SM (1938) Muraqqa-e-Mooltan. Jazib Publishers, Lahore, Pakistan.

15. Garret, H (1968) The Punjab- A hundred Years Ago. Languages Department, Patiala, India.

16. Grewal, J (1990) The Sikhs of the Punjab (Vol. 2). Cambridge University Press, New York.

17. Grewal, JS, Banga, I (1975) Early Nineteenth Century Punjab. Guru Nanak Dev University, Amritsar, India.

18. Singh, B (1990) Maharaja Ranjit Singh and His Times. Sehgal Publishers, New Delhi, India.

19. Singh, F (1982) Some Aspects of State and Society under Maharaja Ranjit Singh. Oriental Publishers, New Delhi, India. 


\section{Annals of Social Sciences \& Management studies}

20. Singh, G (1952) The Punjab in 1839-40. Punjab Intelligence Paper Amritsar, India.

21. Singh, GG (1970) Tawarikh Guru Khalsa (Vol. 2). Bhasha Vibhag Patiala, India.

22. Bell, E (1983) Annexation of the Punjab and Maharaja Duleep Singh. Nirmal Publishers, New Delhi, India.

23. Wadehra, GD (1885) Chahar Bagh-i-Punjab. Punjab State Archives, Patiala, India.

24. Chand, MH (1884) Tawarikh-i-Zila Multan. New Imperial Press and Publications, Lahore, Pakistan.

25. Fagan, P (1884) District Gazetteer of Montgomery District 1883-84. Govt. of the Punjab, Lahore, Pakistan.

26. Govt. of the Punjab (1884) District Gazetteer of Multan 1883-84. Arya Press, Lahore, Pakistan.

27. Govt. of the Punjab (1884) Gazetteer of the Muzaffargarh District 1883-84. Arya Press, Lahore, Pakistan.

28. Malleson, CG (1883) Decisive Battles of India from 1746 to 1849 inclusive. W.H. Allen \& Co, London, UK.

29. Morris, J (1860) Report of the Revised Settlement of Gujranwala District in Lahore Division. Govt. of the Punjab, Lahore, Pakistan.

30. Vigne, G (1840) A Personal Narrative of a Visit of Ghuzni, Kabul and Afghanistan (Vol. 2). G. Routledge, London, UK.

31. Foreign Department (1840) Secret Consultation. National Archives of India, New Delhi, India.

32. Foreign Department (1849) Secret Consultation. National Archives of India, New Delhi, India.

33. Foreign Department (1848) Secret Consultation. National Archives of India, New Delhi, India.

34. Foreign Department (1850) Secret Consultation. National Archives of India, New Delhi, India.

35. Foreign Department (1840) Secrte Consultation. National Archives of India, New Delhi, India.

36. Foreign Department (1844) Secret Consultation. National Archives of India, New Delhi, India.

37. Walia, JM (1982) Parties and Politics at the Sikh Court 1799-1849. Master Publishers, New Delhi, India.
38. Ball, S (1971) British Policy towards the Punjab 1844-49. New Age Publishers, Calcutta, India.

39. Prashad, D (2003) Tarikh-i-Punjab. Nawal Kishore Press, Lucknow India.

40. Gupta, HR (1956) Panjab on the Eve of First Sikh War. Panjab University, Hoshiarpur, India.

41. Edwards, HB (1851) A Year on the Punjab Frontier 1848-49 (Vol. 1) Richard Bentley, London, UK.

42. McAuliffe, M (1881) The Rise of Amritsar and the Alterations of the Sikh Religion. The Calcutta Review 72(143): 57-75.

43. Murray, W (1846) History of the Punjab (Vol. 2). William Allen, London, UK.

44. Roseberry, JR (1987) Imperial Rule in Punjab: The Conquest and Administration of Multan 1818-1881. Manohar Publishers, New Delhi, India.

45. Khilnani, N (1971) British Power in the Punjab 1839-1858. Asia Publishing House, New Delhi, India.

46. Festing, G (1914) Stranger within the Gates. William Blackwood and Sons, London, UK.

47. Griffin, LH (1890) The Punjab Chiefs: Historical and Biographica Notices of the Principal Families. Civil and Military Gazette Press, Lahore, Pakistan.

48. Govt. Record (1915) Lahore Political Dairies 1847-49 (Vol. 5). Punjab Govt. Press, Lahore, Pakistan.

49. Fryer, F (1876) Final Report of the First Regular Settlement of Dera Ghazi Khan in Derajat Division 1869-1874. Govt. of the Punjab, Lahore, Pakistan.

50. Masson, C. (1974) Narrative of various Journeys in Baluchistan Afghanistan and the Punjab (Vol. 1). Oxford University Press, Karachi, Pakistan.

51. Purser, W (1868) Final Report of the Revised Settlement of Jalandhar District in the Punjab 1860-1866. Govt. of the Punjab, Lahore, Pakistan.

52. Roe, C, \& Purser, W (1878) Report of the Revised Land Revenue Settlement of the Montgomery District 1874. Govt. of the Punjab, Lahore, Pakistan.

Your next submission with Juniper Publishers
will reach you the below assets
- Quality Editorial service
- Swift Peer Review
- Reprints availability
- E-prints Service
- Manuscript Podcast for convenient understanding
- Global attainment for your research
- Manuscript accessibility in different formats
( Pdf, E-pub, Full Text, Audio)
- Unceasing customer service
Track the below URL for one-step submission
https://juniperpublishers.com/online-submission.php

